\title{
Antibacterial activity and mechanism of action of trigonostemone against Staphylococcus aureus and Bacillus cereus
}

\author{
Sangdee, A. ${ }^{1}$, Sangdee, K. $^{2}$, Bunchalee, P., ${ }^{1}$ Seephonkai, P. ${ }^{3 *}$ \\ ${ }^{1}$ Department of Biology, Faculty of Science, Mahasarakham University, Khamriang, Kantarawichai, Maha Sarakham, 44150, Thailand \\ ${ }^{2}$ Faculty of Medicine, Mahasarakham University, Muang, Maha Sarakham, 44000, Thailand \\ ${ }^{3}$ Department of Chemistry, Faculty of Science, Mahasarakham University and Center of Excellence for Innovation in Chemistry, Khamriang, \\ Kantarawichai, Maha Sarakham, 44150, Thailand \\ *Corresponding author: prapairat.s@msu.ac.th
}

\section{ARTICLE HISTORY}

Received: 15 July 2021

Revised: 15 September 2021

Accepted: 15 September 2021

Published: 21 December 2021

\begin{abstract}
In our present study, the hexane fraction from the root of the Thai medicinal plant Strophioblachia fimbricalyx Boerl. was purified and the purification led to the isolation of 3-acetylaleuritolic acid, trigonostemone and 3,6,9-trimethoxyphenanthropolone. The aims of this work are to evaluate antibacterial activity of these three isolated compounds from our local plant and to study their mechanism of actions toward target pathogenic bacteria (Gram positive and Gram negative bacteria). The antibacterial activity of isolated compounds was primary screened by agar well diffusion method and the active compound was subjected to determine for MIC and MBC values by microdilution method. The kinetic study of the bacteriostatic or bactericidal activity time-kill experiment $(24 \mathrm{~h})$ and mechanism of action on cell morphology toward target bacteria detected by scanning electron microscope of the active compound were further evaluated. Results indicate that among the tested three compounds, trigonostemone was the only active one. It exhibited an inhibitory effect on the growth of Gram positive bacteria, methicillin-susceptible Staphylococcus aureus (MSSA) DMST 2933, methicillin-resistant S. aureus (MRSA) DMST 20651 and Bacillus cereus ATCC 11778 with the MIC/MBC values of $12.5 / 25.0,6.25 / 6.25$ and $6.25 / 6.25 \mathrm{mg} / \mathrm{mL}$, respectively. Trigonostemone possessed time- and concentration-dependent bacteriostatic activity against $S$. aureus (MSSA) DMST 2933 and bactericidal activity against B. cereus ATCC 11778. It caused bacteriostatic activity against S. aureus (MSSA) DMST 2933 at the concentration of $2 \times$ MIC by changing cell morphology and bactericidal activity against $B$. cereus ATCC 11778 at the concentration of $2 \times$ MIC after $4 \mathrm{~h}$ by inducing cell size variations at the concentrations of $2 \times$ MIC, respectively. This finding suggests that trigonostemone isolated from the root of S. fimbricalyx has a potential to be used as natural antibacterial compound against S. aureus (MSSA) DMST 2933 and B. cereus ATCC 11778 bacterial strains.
\end{abstract}

Keywords: Antibacterial activity; mechanism of action; trigonostemone; Strophioblachia fimbricalyx; time-kill assay.

\section{INTRODUCTION}

Strophioblachia fimbricalyx Boerl. (Euphorbiaceae) is an indigenous plant and distributed widely in northeastern Thailand. Its roots have been used traditionally as treatments for migraine, fever and cancer (Chuakul et al., 2002; Kaewkrud et al., 2008; Seephonkai et al., 2009). The isolation of trigonostemone, 9-O-demethyl trigonostemone, 3,6,9-trimethoxy phenanthropolone, 4,6,9-trimethoxyphenanthropolone, fimbricalyxs A-D, fimbricalyx- anhydrides $A$ and $B$, and fimbricalyxlactones A-D from the ethyl acetate extract from roots of S. fimbricalyx have been reported by our research group (Seephonkai et al., 2009, 2013a, 2013b). Cytotoxic and antiplasmodial activities of the isolated compounds correlated well to the traditional use of this plant. Among these secondary metabolites, trigonostemone was isolated as a major compound and it did not show cytotoxic or antiplasmodial properties toward the tested cancer cells or plasmodial parasite (Seephonkai et al., 2009). Utilization of trigonostemone caught our attention recently due to its antibacterial activity against Staphylococcus aureus (Li et al., 2014).

Microbial infections are a global health problem (Zhao et al., 2014; Khameneh et al., 2019) and infection of foodborne pathogens make an important contribution to this problem. A number of foodborne pathogens have been recognized for foodborne diseases (Alocilja \& Radke 2003; Chemburu et al., 2005; Velusamy et al., 2010). In Thailand, there were about 
$1,038,349$ cases of diarrhea and 110,396 cases of foodborne diseases reported in 2017, and Staphylococcus, Salmonella and Vibrio were the three mains foodborne pathogenic bacteria causing these illnesses (Innovation and Research Division, 2019). Unfortunately, inappropriate use or overuse of antibiotic drugs for medication resulted in drug resistance problems. Therefore, a search for new potential antibacterial agents is needed especially for agents to treat drug resistant bacteria strains and plant secondary metabolites are considered good candidates that could be alternative to antibiotics and for the treatment of antibiotic-resistant bacteria.

In our present study, the hexane fraction from the root of S. fimbricalyx was purified and isolated compounds have been tested for their antibacterial activities against Gram positive and Gram negative foodborne pathogenic bacteria. Kinetic and mechanism of action of active compound were also investigated.

\section{MATERIALS AND METHODS}

\section{General experimental procedure}

Proton nuclear magnetic resonance $\left({ }^{1} \mathrm{H}-\mathrm{NMR} ; 500 \mathrm{MHz}\right)$ spectra were recorded in deuterated chloroform $\left(\mathrm{CDCl}_{3}\right)$. Thin layer chromatography (TLC) technique was performed on aluminum-backed silica gel (60 GF254), and bands were detected by UV light ( $\lambda 254 \mathrm{~nm}$ ). Column chromatography (CC) was performed using silica gel $(40-63 \mu \mathrm{m})$. Scanning electron micrograph was obtained from Scanning Electron Microscope (SEM) (JEOL, JSM6460LV). The bacteria strains were sourced from the Medical Microorganisms Department of Medical Sciences Thailand. Mueller Hinton Agar (MHA) and Mueller Hinton Broth (MHB) (Difco, USA) were used as the culture medium. Tetracycline (Sigma, USA) was used as a standard antibiotic.

\section{Plant material and extraction}

Plant material and extraction of the root of S. fimbricalyx have been described and reported previously (Seephonkai et al., 2013b). The hexane extract (HF-H; $10 \mathrm{~g}$ ), a semi-amorphous brownish-yellow solid, obtaining from our previous study, was triturated in $30 \mathrm{~mL}$ of hexane (stirred, room temperature, $1 \mathrm{~h})$. The brownish-yellow soluble part was taken and the dark brown precipitate was subjected to triturate by the same procedure once again. The hexane soluble filtrate parts were combined and concentrated under reduced pressure while the precipitate was collected and dried to obtain SF-Hf (2.3 g) and SF-Hp (7.5 g) hexane fractions respectively (Figure 1).

\section{Isolation}

Based on TLC profiles and ${ }^{1} \mathrm{H}-\mathrm{NMR}$ spectra, the SF-Hp fraction was subjected to purify (Figure 1) by silica gel column chromatography and eluted with hexane:dichloromethane (80:20 to $20: 80)$ to obtain four major fractions, A (105 mg), $B(1.14 \mathrm{~g}), C(300 \mathrm{mg})$, and D (125 mg). Fractions A and B were combined due to its similarity of the TLC profiles and ${ }^{1} \mathrm{H}-\mathrm{NMR}$ spectra. After that, the combined fraction ( $1.245 \mathrm{~g}$ ) was placed into a glass vial and hexane $(15 \mathrm{~mL})$ was added. The mixture was stirred at room temperature $(1 \mathrm{~h})$, left until powder part at bottom and filtrate on top are separated. Later the filtrated is removed and the same procedure (trituration) was repeated trice with the powder which is identified as 3-acetylaleuritolic acid or acetylaleuritolic acid (a colorless powder; $383 \mathrm{mg}$ ). Fraction $\mathrm{C}$ was chromatographed on silica gel and eluted with hexane:dichloromethane (50:50 to $0: 100)$ followed by dichloromethane:ethyl acetate (90:10 to 70:30). Main sub-fraction was collected and further purified by the same process until obtained trigonostemone (a yellow powder; $180 \mathrm{mg}$ ). Fraction D was subjected to column chromatography over silica gel (dichloromethane:

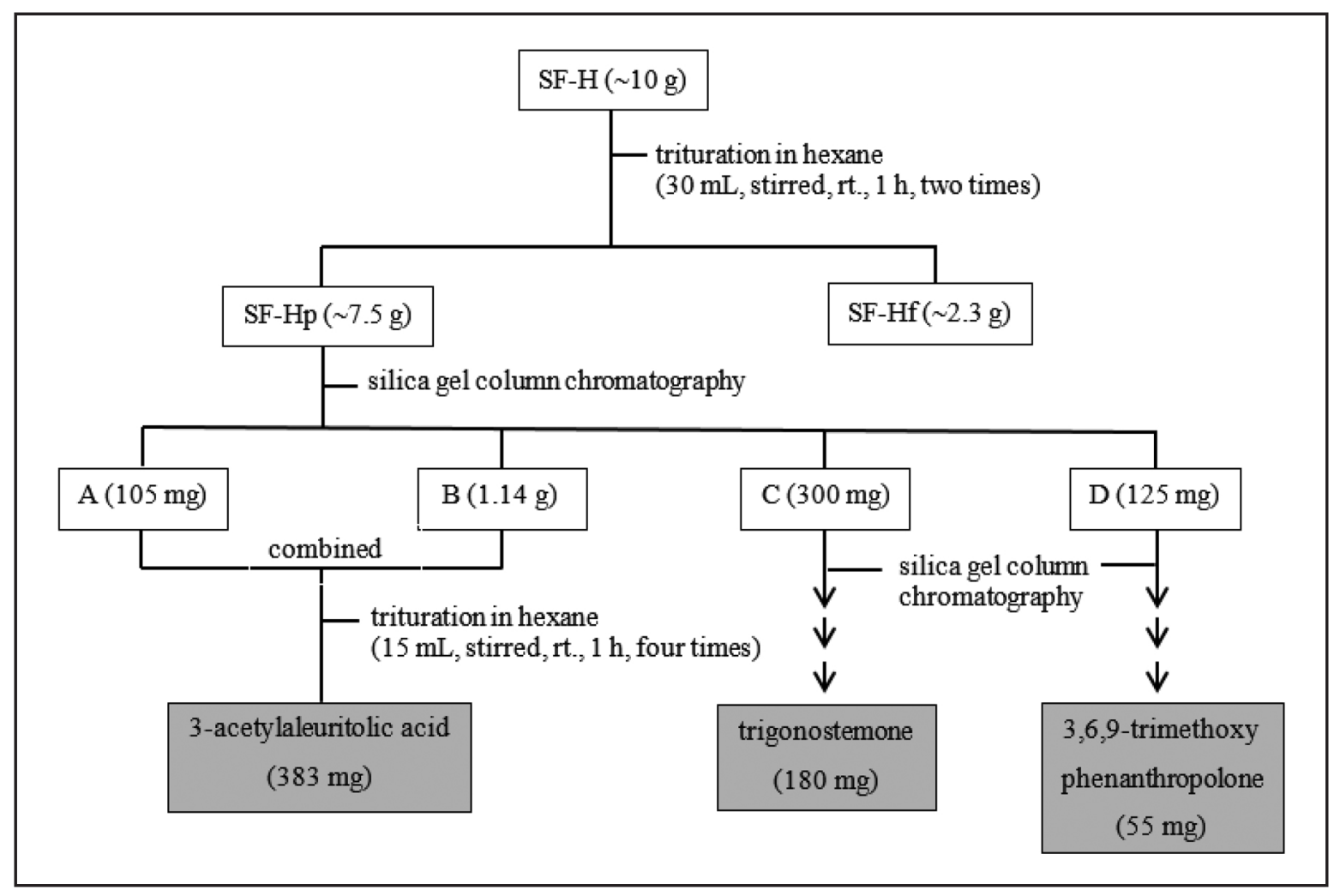

Figure 1. Extraction and isolation flow chart of the hexane fraction from S. fimbricalyx. 
ethyl acetate $=90: 10$ to $30: 70$ as eluent) and main subfaction was re-fractionated on silica gel until gave 3,6,9trimethoxyphenanthropolone (a yellow powder, $55 \mathrm{mg}$ ).

\section{Antibacterial assay}

\section{Bacterial strains and cultivation}

Eight foodborne pathogenic bacteria; three Gram positive bacteria, Staphylococcus aureus (MSSA; methicillin-susceptible) DMST 2933, S. aureus (MRSA; methicillin-resistant strain) DMST 20651 and Bacillus cereus ATCC 11778 and five Gram negative bacteria, Escherichia coli ATCC 25922, Salmonella enterica serovar Typhi DMST 22842, Vibrio cholerae O1 DMST 9700, Shigella flexneri DMST 4423 and Shigella dysenteriae DMST 15110 were selected. The culture of the selected strain was done on Mueller Hinton Agar (MHA) medium $\left(37^{\circ} \mathrm{C}, 16-18 \mathrm{~h}\right)$. Then, single colony of bacterial pathogens was inoculated into Mueller Hinton Broth (MHB) $\left(37^{\circ} \mathrm{C}, 4 \mathrm{~h}, 250 \mathrm{rpm}\right)$. After that, adjustment to 4-5 $\times 10^{6} \mathrm{CFU} / \mathrm{mL}$ of bacterial culture was done.

\section{Antibacterial activity screening}

The agar well diffusion method was performed as preliminary screening of the antibacterial capacity of isolated compounds (Sangdee et al., 2015). The tested bacteria were cultured on $\mathrm{MHB}\left(37^{\circ} \mathrm{C}, 4 \mathrm{~h}, 250 \mathrm{rpm}\right)$ and then adjusted to the 0.5 McFarland standard. The standardized bacterial was swabbed over the whole surface of MHB medium, four directions, and then a $7 \mathrm{~mm}$ sterile cork borer was used to cut the medium. The sample solution $(50 \mathrm{mg} / \mathrm{mL}$ in $10 \%$ methanol) was transferred into the wells and the plates were subjected to incubate $\left(37^{\circ} \mathrm{C}, 16-18 \mathrm{~h}\right)$. Later, the measurement of the inhibitory zone surrounding in each well was read with the help of a Vernier caliper. The standard antibiotic tetracycline was a positive control in this assay. The compound that showed antibacterial activity was chosen for further investigation.

\section{MIC and MBC determination}

The active compound from the antibacterial activity screening was taken to determine MIC and MBC using microdilution method (Sangdee et al., 2018a). Briefly, the tested bacteria were cultured as described above (MHA medium, $37^{\circ} \mathrm{C}, 4 \mathrm{~h}$, $250 \mathrm{rpm}$, followed by adjustment to the $0.5 \mathrm{McF}$ arland standard). Then, the standardized inoculum of $4-5 \times 10^{6} \mathrm{CFU} /$ $\mathrm{mL}(10 \mu \mathrm{L})$ was applied to the wells (96-well polystyrene plate) and each diluted sample solution $(50,25,12.5,6.25$, 3.125 and $1.56 \mathrm{mg} / \mathrm{mL})$ in $\mathrm{MHB}(90 \mu \mathrm{L})$ was added. Inoculated and uninoculated controls were included each in their own separated well plate. A reference tetracycline compound (250 $\mu \mathrm{g} / \mathrm{mL}$ ) was used as positive control. The plates were incubated $\left(37^{\circ} \mathrm{C}, 16-18 \mathrm{~h}\right)$ and the minimum inhibitory concentration (MIC) to inhibit the growth of tested bacterial, was determined. Later, the subculture of suspension in each well was performed on MHA to record the minimum bactericidal concentration $(\mathrm{MBC})$ to kill the tested bacteria.

\section{Time-kill assay}

The experiment of time-kill was done as described in the literatures (White et al., 1996; Aiyegoro et al., 2009; Alshareef, 2021) for the active compound. The concentration of $2 \times$ MIC of the sample solution was used to test against target bacteria along with the test tube of MHB without sample and $\mathrm{MHB}$ with tetracycline $(250 \mu \mathrm{g} / \mathrm{mL})$ in the assay. After incubation $\left(37^{\circ} \mathrm{C}\right)$, bacterial suspension in a small volume was taken at $0,2,4$, and $24 \mathrm{~h}$ to dilute and spread onto the MHA plate in order to count the viable colony number. A graph between viable bacteria number and time taken was plotted to evaluate the killing rate. Results with bacterial count reduction of $3 \log 10$ (Pankey \& Sabath, 2004) were considered to have bactericidal activity.

\section{SEM experiment}

The mechanism of actions on target bacterial cell morphology of the active compound was investigated using scanning electron microscope (SEM) experiments as described in literature (Sangdee et al., 2018b). The pathogen cells were treated with the sample solution at $2 \times$ MIC level of the concentration, and were then incubated $\left(37^{\circ} \mathrm{C}, 16-18 \mathrm{~h}\right)$. Next, the bacterial cells were harvested and washed, and fixed with $2.5 \%$ glutaraldehyde in $5 \%$ sucrose. After that, the cell pellets were dehydrated and then applied to a membrane. Gold was used to sputter-coat onto a dried sample powder surface for preparing samples which were taken to morphologically examine under a SEM. The cell alterations caused by compound treatment were compared with those caused by tetracycline $(250 \mu \mathrm{g} / \mathrm{mL})$ and the control treatments.

\section{Statistical analysis}

The data from three replicates were presented as mean using Microsoft ${ }^{\circledR}$ Excel $^{\circledR} 2016$ (Microsoft Corporation, Redmond, USA). Then, the time-kill kinetics were plot using Microsoft ${ }^{\circledast}$ Excel $^{\circledR}$ 2016.

\section{RESULTS AND DISCUSSION}

\section{Identification of compound}

Three isolated compounds; 3-acetylaleuritolic acid, trigonostemone and 3,6,9-trimethoxy phenanthropolone (Figure 2), were identified based on comparison of their ${ }^{1} \mathrm{H}-\mathrm{NMR}$ spectra to those reported in literatures (McLean et al., 1987; Seephonkai et al., 2009). Both 3-acetyl aleuritic acid and trigonostemon have been isolated previously from the root of the Thai medicinal plant Trigonostemon reidioides Criab. (Euphorbiaceae) (Vipha, 1988; Kokpol et al., 1990). Our present study supported the co-occurrence of these two metabolites from S. fimbricalyx which belongs to Euphorbiaceae family.

\section{Antibacterial activity screening and $\mathrm{MIC}$ and $\mathrm{MBC}$ determination} The results from preliminary screening of antibacterial activity against eight foodborne pathogenic bacteria showed that trigonostemone had the growth inhibitory activity toward all three Gram positive bacteria; S. aureus (MSSA) DMST 2933, S. aureus (MRSA) DMST 20651 and Bacillus cereus ATCC 11778. Its inhibitory zone of $17-18 \mathrm{~mm}$ for both $S$. aureus strains and 14 mm for B. cereus ATCC 11778 was observed (Table 1). No activity of this compound against Gram negative bacteria used in this study was observed. The MIC and MBC were next determined toward target bacteria. The results showed that the MIC of trigonostemone was low, ranging from 6.25-12.50 $\mathrm{mg} / \mathrm{mL}$ (Table 1). Among the three target tested bacteria, trigonostemone exhibited the most potent activity with MIC values of 6.25 and $6.25 \mathrm{mg} / \mathrm{mL}$ and $\mathrm{MBC}$ value was 6.25 and $6.25 \mathrm{mg} / \mathrm{mL}$ against S. aureus (MRSA) DMST 20651 and B. cereus, respectively.

\section{Time-kill assay}

The time-kill assay was carried out for determining trigonostemone bacteriostatic/bactericidal activity. The time kill profiles of trigonostemone $(2 \times \mathrm{MIC})$ exhibited bacteriostatic activity toward S. aureus (MSSA) DMST 2933 (Figure $3 \mathrm{~A})$ compared with the other concentrations $(0.5 \times$ MIC and $1 \times$ MIC). The trigonostemone was bacteriostatic against S. aureus (MRSA) DMST 20651 when the bacterial was 


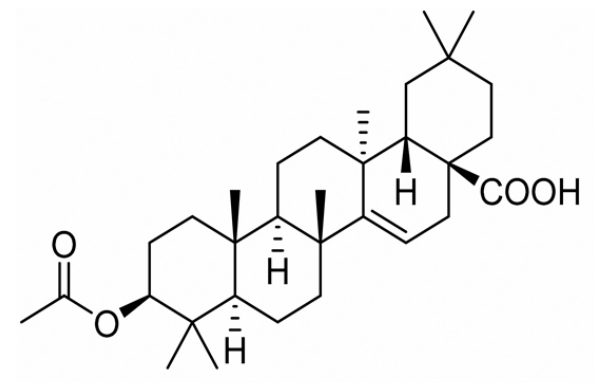

3-acetylaleuritolic acid<smiles>COC1=Cc2c(cc(OC)c3cc(C)c(OC)cc23)C(C)(C)C1=O</smiles>

trigonostemone<smiles>COc1cc2c(cc1C)c(OC)cc1cc(C)c(=O)c(OC)cc12</smiles>

3,6,9-trimethoxyphenanthropolone

Figure 2. Structures of three isolated compounds from S. fimbricalyx.

Table 1. Screening of the antibacterial activity, MIC and MBC of trigonostemone against pathogenic bacteria

\begin{tabular}{lcc}
\hline Strains & Inhibition zone diameter $(\mathrm{mm})$ & $\mathrm{MIC}(\mathrm{mg} / \mathrm{mL})$ \\
\hline Escherichia coli ATCC 25922 & 0 & ND \\
Salmonella enterica serovar Typhi DMST 22842 & ND & ND \\
Shigella flexneri DMST 4423 & 0 & ND \\
Shigella dysenteriae DMST 15110 & 0 & ND \\
Vibrio cholerae O1 DMST 9700 & 0 & ND \\
Staphylococcus aureus MSSA 2933 & 0 & ND \\
Staphylococcus aureus MRSA 20651 & $17 \times 17$ & ND \\
Bacillus cereus ATCC11778 & $18 \times 18$ & 6.50 \\
\end{tabular}

ND means not determined. Data represented as a mean value from experiment in triplicate.

initially exposed to the compound ( $<4 \mathrm{~h}$ ) (Figure 3B), but was no bacteriostatic toward S. aureus (MRSA) DMST 20651, after exposed time of more than $4 \mathrm{~h}$ (Figure 3B). Interestingly, this compound $(2 \times \mathrm{MIC})$ reduced $B$. cereus ATCC 11778 cell viability at the level of $3 \log _{10} \mathrm{CFU} / \mathrm{mL}$ by $24 \mathrm{~h}$ (Figure $3 \mathrm{C}$ ), indicating that bactericidal activity of trigonostemone toward this bacterial strain. Based on these results it was concluded that trigonostemone has time- and concentration-dependent bacteriostatic and bactericidal activities against $S$. aureus (MSSA) DMST 2933 and B. cereus ATCC 11778, respectively.

\section{SEM experiment}

The cell morphology of the target bacteria was investigated after the treatment with trigonostemone using SEM. In the case of $S$. aureus, several cell alterations induced by trigonostemone $(2 \times \mathrm{MIC})$ and tetracycline were observed clearly. These include either decrease or increase cell size (Figure 4B, C, E and F). Similar results of morphological alterations were observed when $B$. cereus ATCC 11778 was treated with trigonostemone $(2 \times \mathrm{MIC})$ (Figure $5 \mathrm{C}$ ). Cell lysis or bacterial cell cavities of $B$. cereus ATCC 11778 was observed after the treatment with tetracycline while there was no damaging of untreated control (Figure 4A, D and Figure 5A).

To our knowledge, only one example of antimicrobial activity of trigonochinene $E$, a phenanthrene, with chemical structure closely related to trigonostemone has been reported (Yin et al., 2008). This compound exhibited the inhibition activity against selective Gram-positive bacteria S. aureus ATCC 25923, S. epidermidis ATCC 12228 and Micrococcus luteus ATCC 9341 (MIC values $6.25-12.5 \mu \mathrm{g} / \mathrm{mL}$ ). This information may suggest that phenanthrene and phenanthrenone compounds are effective against Gram positive bacteria.
The activity of trigonostemone against Gram-negative bacteria was not observed in this study. This was probably because the mechanism of action of the tested compound respond to different target molecules in Gram negative and Gram positive bacteria cell wall structure (Russell, 2003). Blestriacin, a Gram-positive dihydro-biphenanthrene bactericidal agent, is a good examples. The antibacterial activity and antibacterial mechanism of blestriacin has been investigated recently (Qian et al., 2015; Chen et al., 2018). Numerous lysed cells of S. aureus ATCC 2931 and cellular fragment were observed when blestriacin was treated with the bacteria. The change of morphology and fragmentation of Bacillus subtilis 168 structure cell were also induced by this compound (Qian et al., 2015; Chen et al., 2018). These effects on the bacteria cell membrane were similar to the observation of S. aureus (MSSA) DMST 2933 and B. cereus ATCC 11778 treated with trigonostemone in our present study. Based on the bacterial cell alteration results in this study, a trigonostemone mechanism of action involving peptidoglycan biosynthesis disruption resulting in bacterial cell wall damage and causing cell death (Cushnie et al., 2016) could be concluded.

\section{CONCLUSION}

This work reports the antibacterial activity of the trigonostemone together with its kinetic and mechanism of action. It exhibited time- and concentration-dependent bacteriostatic activity against S. aureus (MSSA) DMST 2933 and bactericidal activity against $B$. cereus ATCC 11778 by changing cell morphology and cell lysis. 


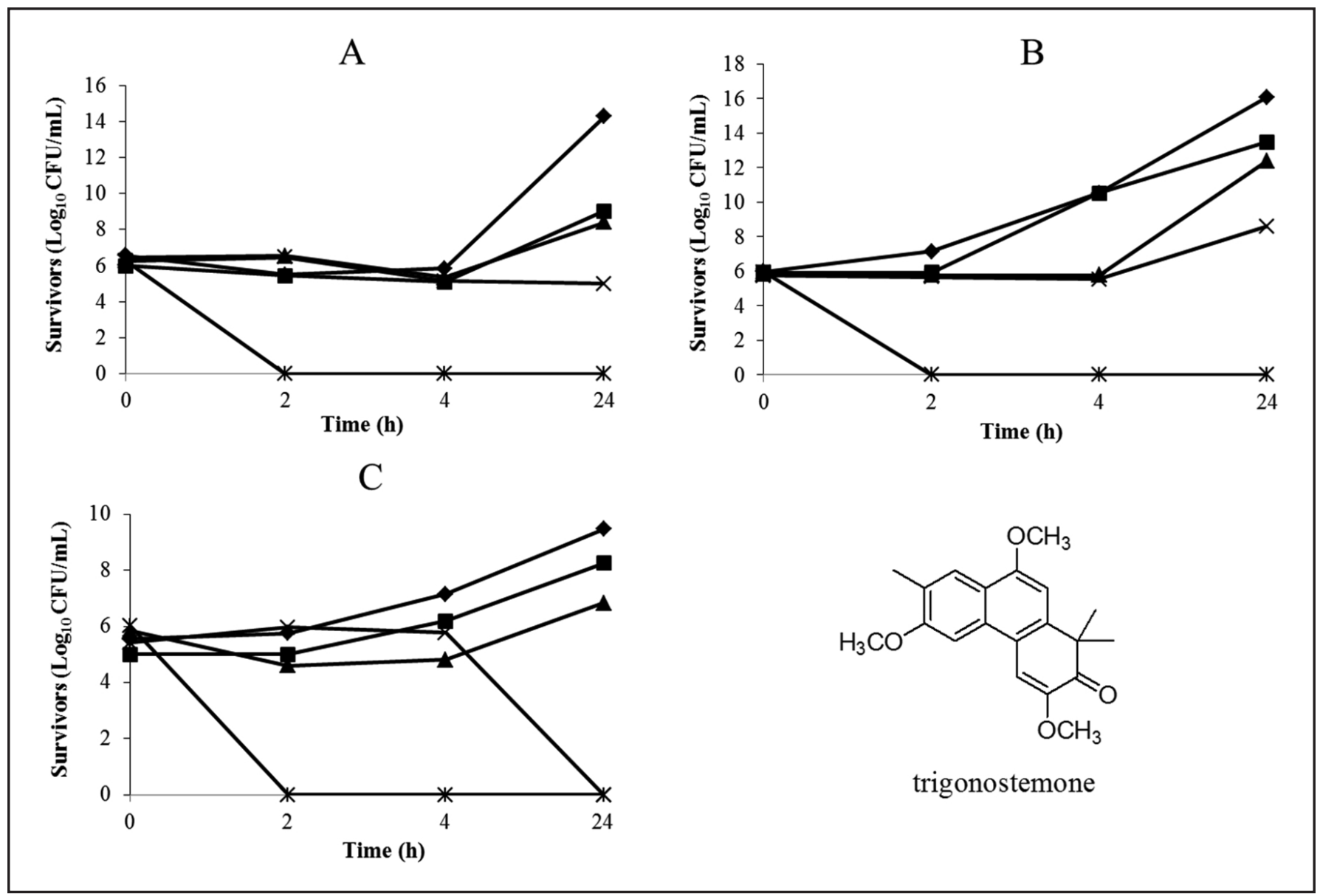

Figure 3. In vitro bacteriostatic and bacteriocidal activities of trigonostemone against S. aureus (MSSA) DMST 2933 (A), S. aureus (MRSA) DMST 20651 (B) and B. cereus ATCC 11778 (C) at $0.5 \times$ MIC ( $\mathbf{\square}), 1 \times$ MIC (A), and $2 \times$ MIC (x) compared with the untreated control $(\$)$ and tetracycline at $250 \mu \mathrm{g} / \mathrm{mL}(*)$. Data represent mean from three replicates.

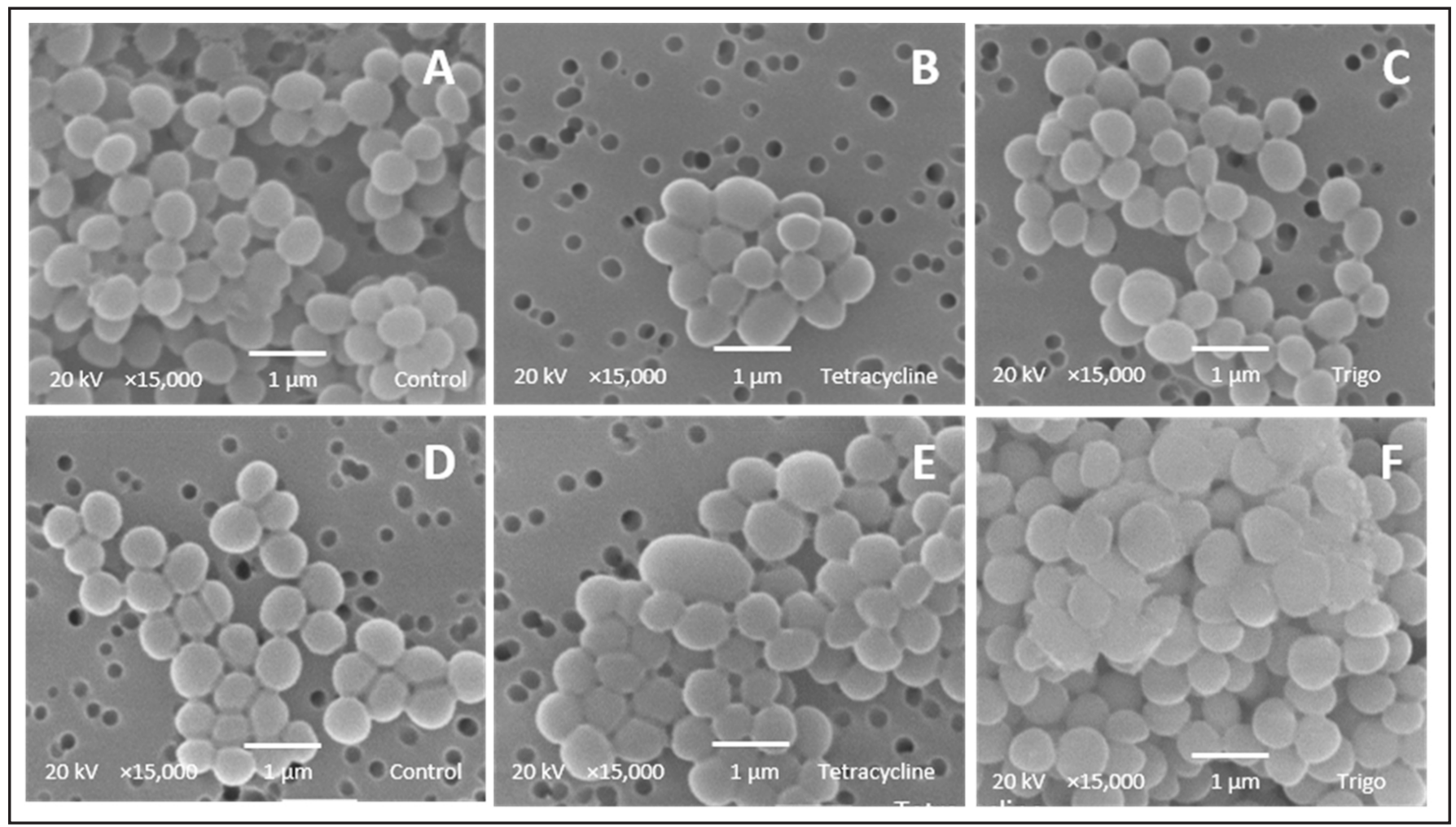

Figure 4. Scanning electron micrographs shows the cell morphological alteration such as decrease and increase of cell size of S. aureus (MSSA) DMST 2933 (A-C) and S. aureus (MRSA) DMST 20651 (D-F) after the treatment with trigonostemone at $2 \times$ MIC (C and $F)$, and tetracycline at $250 \mu \mathrm{g} / \mathrm{mL}$ ( $B$ and $E$ ) compared with the normal cell size in the untreated control treatment (A and $D)$. 


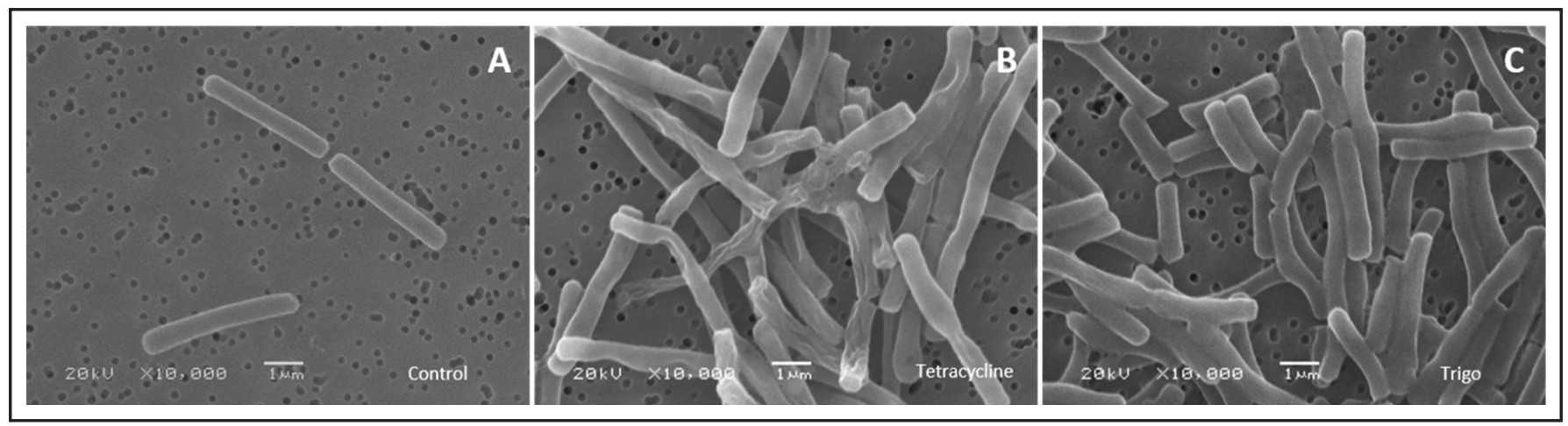

Figure 5. Scanning electron micrographs shows the cell size variation of B. cereus ATCC 11778 after the treatment with trigonostemone at $2 \times$ MIC (C) and the cell cavities was observed in the tetracycline at $250 \mu \mathrm{g} / \mathrm{mL}$ treatment (B) compared with the normal cell in the untreated control treatment $(A)$.

\section{ACKNOWLEDGMENTS}

This research project was financially supported by Mahasarakham University (MSU). PS thanks to the Faculty of Science, MSU.

\section{Conflict of interest}

We declared that there is no conflict of interest.

\section{REFERENCES}

Aiyegoro, O.A., Afolayan, A.J. \& Okoh, A.I. (2009). In vitro antibacterial time kill studies of leaves extracts of Helichrysum longifolium. Journal of Medicinal Plant Research 3: $462-467$.

Alocilja, E.C. \& Radke, S.M. (2003). Market analysis of biosensor for food safety. Biosensors and Bioelectronics 18: 841-846. https://doi.org/10.1016/S0956-5663(03)00009-5

Alshareef, F. (2021). Protocol to evaluate antibacterial activity MIC, FIC and time kill method. Acta Scientific Microbiology 4: 2-6.

Chemburu, S., Wilkins, E. \& Abdel-Hamid, I. (2005). Detection of pathogenic bacteria in food samples using highlydispersed carbon particles. Biosensors and Bioelectronics 21: 491-499. https://doi.org/10.1016/j.bios.2004.11.025

Chen, B.C., Lin, C.X., Chen, N.P., Gao, C.X., Zhao, Y.J. \& Qian, C.D. (2018). Phenanthrene antibiotic targets bacterial membranes and kill Staphylococcus aureus with a low propensity for resistance development. Frontiers in Microbiology 9: 19. https://doi.org/10.3389/fmicb.2018.01593

Chuakul, W., Saralamp, P. \& Boonpleng, A. (2002). Medicinal plants used in the Kutchum District, Yasothon Province, Thailand. Thai Journal of Phytopharmacy 9: 22-49.

Cushnie, T.P.T., O’Driscoll, N.H. \& Lamb, A.J. (2016). Morphological and ultrastructural changes in bacterial cells as an indicator of antibacterial mechanism of action. Cellular and Molecular Life Sciences 73: 4471-4492. https:// doi.org/10.1007/s00018-016-2302-2

Innovation and Research Division (2019). Prevention research plan disease and health problem control 2019-2021. Department of Disease Control, Ministry of Public Health. 2019. pp. 7-9. https://irem.ddc.moph.go.th/uploads/book/ 5c779c5c14610.pdf. Accessed 11 May 2020.

Kaewkrud, W., Otsuka, H., Ruchirawat, S. \& Kanchanapoom, T. (2008). Megastigmane and flavone glycoside from Strophioblachia fimbrocalyx Boerl. Journal of Natural Medicine 62: 124125. https://doi.org/10.1007/s11418-007-0192-1
Khameneh, B., Iranshahy, M., Soheili, V. \& Bazzaz, B.S.F. (2019). Review on plant antimicrobials: a mechanistic viewpoint. Antimicrobial Resistant \& Infection Control 8: 118. https:// doi.org/10.1186/s13756-019-0559-6

Kokpol, U., Thebpatiphat, S., Boonyaratavej, S., Chedchuskulcai, V., Ni, C.Z., Clardy, J., Chaichantipyuth, C., Chittawong, V. \& Miles, D.H. (1990). Structure of trigonostemone, a new phenanthrenone from the Thai plant Trigonostemon reidioides. Journal of Natural Products 53: 1148-1151. https://doi.org/10.1021/np50071a002

Li, Y.X., Zuo, W.J., Mei, W.L., Chen, H.G. \& Dai, H.F. (2014). A new diterpenese from the stem of Trigonostemon heterophyllus. Chinese Journal of Natural Medicines 12: 297-299. https://doi.org/10.1016/S1875-5364(14)60058-3

McLean, S., Perpick-Dumont, M., Reynolds, W.F., Jacobs, H. \& Lachmensing, S.S. (1987). Unambiguous structure and nuclear magnetic resonance characterization of two triterpenoids of Maptounea guianensis by two-dimensional nuclear magnetic resonance spectroscopy. Canadian Journal of Chemistry 65: 2519-2525. https://doi.org/10.1139/ v87-420

Pankey, G.A. \& Sabath, L.D. (2004). Clinical relevance of bacteriostatic versus bactericidal Mechanisms of action in the treatment of gram-positive bacterial infections. Clinical Infectious Diseases 38: 864-870. https://doi.org/ 10.1086/381972

Qian, C.D., Jiang, F.S., Yu, H.S., Shen, Y., Fu, Y.H., Chen, D.Q., Gan, L.S. \& Ding, Z.S. (2015). Antibacterial biphenanthrenes from the fibrous roots of Bletilla striata. Journal of Natural Products 78: 939-943. https://doi.org/10.1021/ np501012n

Russell, A.D. (2003). Similarities and differences in the responses of microorganisms to biocides. Journal of Antimicrobial Chemotherapy 52: 750-763. https://doi.org/ $10.1093 / \mathrm{jac} / \mathrm{dkg} 422$

Sangdee, K., Nakbanpote, W. \& Sangdee, A, (2015). Isolation of the entomopathogenic fungal strain Cod-MK1201 from a cicada nymph and assessment of its antibacterial activities. International Journal of Medicinal Mushrooms 17: 51-63. https://doi.org/10.1615/intjmedmushrooms. v17.i1.60

Sangdee, K., Buranrat, B., Jaihan, P., Thongchai, S. \& Sangdee, A. (2018a). Evaluation of antibacterial and anticancer activities of the medicinal fungus Ophiocordyceps sobolifera (Ascomycetes) from Thailand. International Journal of Medicinal Mushrooms 20: 471-484. https://doi.org/ 10.1615/IntJMedMushrooms.2018026247 
Sangdee, A., Sangdee, K., Buranrat, B. \& Thammawat, S. (2018b), Effects of mycelial extract and crude protein of the medicinal mushroom, Ophiocordyceps sobolifera, on the pathogenic fungus, Candida albicans. Tropical Journal of Pharmaceutical Research 17: 2449-2454. https://doi.org/ 10.4314/tjpr.v17i12.21

Seephonkai, P., Sangdee, A., Bunchalee, P. \& Pyne, S.G. (2009). Cytotoxic and antiplasmodial compounds from the roots of Strophioblachia fimbricalyx. Journal of Natural Products 72: 1892-1894. https://doi.org/10.1021/np900352n

Seephonkai, P., Pyne, S.G., Willis, A.C. \& Lie, W. (2013a). Fimbricalyx $A$, a novel phenanthrenone derivative having a rare $2 \mathrm{H}$-benz[e]inden-2-one substructure. Tetrahedron Letters 54: 2085-2088. https://doi.org/10.1016/j.tetlet.2013. 02.025

Seephonkai, P., Pyne, S.G., Willis, A.C. \& Lie, W. (2013b). Bioactive compounds from the roots of Strophioblachia fimbricalyx. Journal of Natural Products 76: 1358-1364. https:/ /doi.org/10.1021/np400268d
Velusamy, V., Arshak, K., Korostynska, O., Oliwa, K. \& Adley, C. (2010). An overview of foodborne pathogen detection: In the perspective of biosensors. Biotechnology Advances 28: 232-254. https://doi.org/10.1016/j.biotechadv.2009.12.004

Vipha, C. (1988). Dissertation: The isolation and structural elucidation of compounds from roots of Trigonostemon reidioides Craib. Chulalongkorn University.

White, R.L., Burgess, D.S. \& Manduru, M. (1996). Comparison of three different in vitro methods of detecting synergy: time-kill, checkerboard, and E test. Antimicrobial Agents and Chemotherapy 40: 1914-1918.

Yin, S., Su, Z.S., Zhou, Z.W., Dong, L. \& Yue, J.M. (2008). Antimicrobial diterpenes from Trigonostemon chinensis. Journal of Natural Products 71: 1414-1417. https://doi.org/ 10.1021/np800256x

Zhao, X., Lin, C.W., Wang, J. \& Oh, D.H. (2014). Advance in rapid detection methods for foodborne pathogens. Journal of Microbiology and Biotechnology 24: 297-312. https://doi.org/ 10.4014/jmb.1310.10013 